\title{
ЗМІНА НОРМАТИВНОГО СТАТУСУ СОЦАЛЬНОГО АКТУ У ЗВ'ЯЗКУ ІЗ ЗМІНАМИ СОЦІАЛЬНИХ СИСТЕМ: НОРМАТИВНИЙ ПРОСТІР, КОНФЛІКТИ ТА КОМУНІКАЦІЯ
}

Стаття $\epsilon$ відповіддю на виклики сьогодення, породжені соціальними конфліктами та процесами конфліктного протистояння в умовах гібридної війни в Україні, а також спробою простежити динаміку переходу між індивідуальним i соціальним рівнями функціонування в ситуації соціальної напруженості, що дістав назву “"зміни нормативного статусу соціального акту у зв'язку із змінами соціальної системи". Розуміння предмета дослідження спирається на історично зафіксовані здобутки вивчення соціальних структур (Дж. П. Мердок, Т. Парсонс) і процесів системотворення (Г. Щедровицький, Я. Щепанськи), а також різних аспектів імовірності переходу напруженості з одного рівня соціального функціонування на інший. Застосований системний підхід означує ситуацію соціальної напруженості як реакцію на соціальні виклики: з одного боку - захисту власної автономності, з другого - опору опануванню нових пропозицій часу. Нестабільність соціальних систем та ймовірність переходу між ії рівнями фіксуються за допомогою таких понять, як соціальна аномія та соціальні девіації, соціальні норми, соціальна ентропія, корупція - з їхнім впливом на найнижчий (індивідуальний) рівень соціального функціонування шляхом стигматизації процесів узвичаєння як адаптаційних механізмів співіснування в суспільстві. Визначальною особливістю цього процесу визнається закладена норма реакції на гіпотетичні зміни в соціальній системі, що забезпечує таким чином прогнозований напрям їі розвитку, а також вибір засобів відповідно до потрібної інтенсивності збалансування соціальних процесів, спрямовування комунікації або на формування нормативного простору, або на його конфліктну руйнацію. Розроблена автором структурно-функціональна модель аналізу соціальних систем пропонується як пояснювальна щодо вищезазначених процесів.

Ключові слова: психологія соціальної норми, соціальні процеси, нормативний простір, комунікація, конфлікт.

H. M. Bevz

\section{THE CHANGE OF SOCIAL ACTION NORMATIVE STATUS DUE TO THE CHANGES OF SOCIAL SYSTEMS: NORMATIVE SPACE, CONFLICTS AND COMMUNICATION}

The article is a response to today's challenges regarding manifestations of social conflicts and the processes of conflict resistance in the context of the hybrid war in Ukraine. The article is also an attempt to answer the question on the dynamics of transition between the individual and social levels of functioning in a social tension situation, known as "change of social action normative status due to the changes of social system". Research subject understanding relies on historically established achievements in the study of social structures (J. P. Murdoch, T. Parsons) and systemcreation processes (G. Schedrovitskyi, Y. Shchepanskyi) as well as various aspects of the transition probability of tension from one level of social functioning to another. The system approach applied in the article determines the situation of social tension 
as a reaction to the social challenges: on the one hand - to protect self-autonomy, on the other - to resist the familiarization with the innovative propositions. It is stated that the instability of social systems and the probability of transition between its levels are fixed through such concepts as social anomie and social deviations, social norms, social entropy and corruption - with their influence on the lowest (individual) level of social functioning by stigmatization of habituation processes as coexistence adaptation mechanisms in society. The determining part of this process is the established norm of reaction to the hypothetical changes in the social system, which thus ensures the predicted direction of its development, as well as the choice of means of intensity to balance the social processes, as the communication directing either towards the formation of a normative space or towards its conflict destruction. The structure-functional model on the analysis of social systems developed by the author is described as an explanation of the above-mentioned processes.

Key words: psychology of social norm, social processes, normative space, communication, conflict.

Постановка проблеми. Сьогодення однозначно засвідчує, що процеси державотворення в Україні не можна розглядати як рівномірні і сталі. Упродовж періоду становлення суверенної держави Україна зазнала численних критичних впливів, які супроводжувалися спалахами різних соціальних конфліктів, воєнними сутичками, рухами опору i протистояння, а також громадськими ініціативами та розгортанням просоціальних програм підтримки і взаємопідтримки людей у ситуаціях кризи та зубожіння. А проте час плине наскільки стрімко, що чергові зміни критичних соціальних ситуацій перекривають одна одну: ще жива пам'ять про низку політичних акцій протесту громадян проти дій влади, що зафіксувалися в історії як акція “Україна без Кучми”, Помаранчева революція (масові протести проти фальсифікації президентських виборів) і Революція Гідності, а вже болем покрила життя тисяч людей ситуація гібридної війни, що призвела до порушення територіальної цілісності України та вимушених масових переселень. Водночас пришвидшення темпів державного реформування в напрямі децентралізації та утвердження принципів громадянського суспільства вимагають від громадян адекватного долучення до процесу розбудови української державності, що посилює напруженість у соціальній спільноті та зумовлює ризики їі виснаження. Факти щоденних змін засвідчують швидке переміщення ситуацій напруженості та конфліктів із локального на системний рівень і навпаки, що посилює нестабільність соціальної системи і тим самим породжує ризики деструкції та спокусу звернення до “аварійного”, авторитарно-диктаторського, управління задля призупинення подальшої руйнації держави. За таких умов постає необхідність пізнання соціальних процесів системотворення, передусім визначення засобів урегулювання соціальної напруженості ненасильницьким, незбройним шляхом. У цьому контексті видається важливим переглянути наявні теоретичні 
напрацювання в галузі психології соціальних конфліктів, зіставивши їх 3 теоріями розбудови соціальних систем. Таке завдання випливає 3 розуміння того, що процеси системотворення мають як конфліктну, так і ресурсну складові, що є взаємозамінними за різних умов функціонування соціальних систем.

Аналіз останніх досліджень і публікацій. У переліку історично зафіксованих здобутків у вивченні соціальних структур (Дж. П. Мердок, Т. Парсонс) [1] та процесів системотворення (Г. Щедровицький, Я. Щепанський) особливо важливими видаються внески дослідників 3 питань переходу напруженості та локалізації конфлікту з одного рівня соціального функціонування на інший. Різні аспекти ймовірності такого переходу частково розкриваються в працях В. Васютинського в контексті психологічних вимірів спільнот [2], В. Казміренка в описі соціальнопсихологічних чинників політичного вибору особистості [3], а також коли йдеться про питання психологічної безпеки (Я. Подоляк, А. Сухов), що згідно із системним підходом можна трактувати як реакцію на соціальні виклики: 3 одного боку - захисту власної автономності, 3 другого - опору опануванню нових пропозицій часу [3, с. 58].

Не вирішені раніше частини загальної проблеми. За наявності численних досліджень та практик у сфері конфліктології (Ф. Глазл, А. Дмитрієв, А. Ішмуратов, П. Коулман, Т. Крам [4]) питання динаміки співвіднесення індивідуально-психологічних і соціальних детермінант розгортання напружених соціальних процесів усе ще не дістали належного обгрунтування, що й ініціювало цю розвідку. Зрозуміло, ми теж жодним чином не претендуємо на вичерпне вирішення цього завдання, однак маємо за мету виокремити ті психологічні позиції та чинники, які можуть стати місточком, переходом між індивідуальним і соціальним рівнями в ситуації напруженості. Цей перехід ми назвали “зміною нормативного статусу соціального акту у зв’язку із змінами соціальної системи". Відтак було поставлено такі завдання: виокремити соціальнопсихологічні явища, які фіксують переходи в стані соціальних систем (порушення/збалансування), та спробувати прояснити процеси міжрівневого взаємопроникнення соціального та індивідуального, що змінюють як статус самого соціального акту, так і ймовірність змін соціальної системи.

Виклад основного матеріалу дослідження. Перш за все слід відмітити, що категорія конфлікту пов'язана 3 поняттям перебігу часу та характеристиками темпоральності, подійності життя, повсякденними презентаціями та оцінками людини на різних рівнях їі співіснування: індивідуальному, груповому, соціальному та світовому [5]. Останній рівень набуває все більшої ваги для індивідуального життя людини 3 огляду на процеси глобалізації та формування інформаційного простору міжособової взаємодії [6]. Конфлікт як зіткнення в різних формах взає- 
модії може бути представлений у часі, просторі та динаміці свого розгортання на різних рівнях соціальної системи. У певних ситуаціях сила системи (як найвищого рівня соціальної організації) та індивіда (як їі користувача і творця) може врівноважуватися, що уможливлює наскрізний рух для змін самої системи. Однак для індивіда 3 погляду показників його життєздатності такий прорив завжди є надмірним і саме тому не завжди екологічним [там само]. У ситуації занадто швидких змін, що відбуваються в надто короткий час, імовірність перевищення можливостей адаптаційних механізмів людини є занадто високою, що може спровокувати розвиток такого явища, як футурошок (Е. Тоффлер) $[7$, c. 16$]$.

Ситуація соціального конфлікту, спрямованого зазвичай на руйнування обмежень системи, вимагає вирішення завдань завжди вищого рівня, ніж індивідуальний, що, як правило, є непосильним для конкретної людини. Тим самим ініціюється притягнення ресурсів інших рівнів функціонування, стають імовірними як реакції опору, так і сприяння. Одне $з$ тлумачень конфлікту як сутички спирається на оцінку ситуації взаємодії на рівні функціонування суб'єкта взаємодії (індивідуального або групового), що з позиції самої системи може фіксувати стан послаблення іï здатності до звичного врегулювання процесів функціонування. У цьому контексті вагомими видаються ті процеси і явища, які відображають ситуації нестабільності соціальних систем. Наразі виділяємо такі: соціальна аномія, що на індивідуальному рівні функціонування може набувати різних характеристик (з одного боку - від індивідуальних девіацій до масових соціальних явищ, таких як сирітство, споживацтво, а 3 другого - аж до статусу вчинку та переходу між повсякденністю і неповсякденністю в екстремальних ситуаціях $[1 ; 5 ; 8])$; визначення поняття норми, нормування та процеси валоризації (сфера соціальної роботи) а також інклюзивні соціальні процеси, зокрема щодо людей з інвалідністю; соціальна ентропія та корупція - 3 їхнім впливом на найнижчий (індивідуальний) рівень соціального функціонування через стигматизацію процесів узвичаєння як адаптаційних механізмів співіснування в суспільстві [1; 9; 10]. Слід зазначити, що процеси узвичаєння, які формуються за певних умов співіснування (дефіцитарних, обмежених, деприваційних), детермінують розвиток певних психологічних якостей та явищ. У психологічній літературі це зафіксовано щодо різних соціальних ситуацій, які породжують, наприклад, навчену безпорадність, явище споживацтва, феномени “сирітства” та “інвалідизаціі” тощо. Як свідчать наукові дослідження та практика, в таких ситуаціях активізуються зазвичай захисні та компенсаторні механізми: набуваючи ознак провідних, вони змінюють спрямованість розвитку суб'єкта, що забезпечує йому лише певний рівень виживання. Напрацьовані життєвим досвідом, ці механізми можуть, однак, ставати неконструктивними $з$ погляду подальшого розвитку індивіда, а в ситуації 
масовості - становити ризик навіть для системи загалом. Відповідну думку висловив ще А. Маслоу щодо порядку задоволення потреб, де потреби виживання, як базові, активізуються в стресових і загрозливих для життя ситуаціях, відповідним чином формуючи поведінку людини та розвиток ії самосвідомості. Натомість потреби вищого рівня мають більш варіативні стимули і слугують актуалізації та самореалізації людини [11].

Усі перелічені вище ознаки можуть свідчити про актуальні процеси та стани функціонування соціальної системи, фіксуючи ймовірність розмивання іiі меж та уможливлюючи “перекидання" відповідальності між соціальним та індивідуальними рівнями іiі функціонування. У цьому контексті важливим чинником $є$ закладена норма реакції на гіпотетичні зміни в соціальній системі, адже саме вона забезпечує прогнозований напрям розвитку системи, а також вибір засобів збалансування та регулювання інтенсивності перебігу процесів у ній. Таким чином, кожний соціальний акт оцінюється під кутом зору відповідності/невідповідності нормі і супроводжується “нормою реакції, яка виражається в актах схвалення/покарання. На думку автора нормативної концепції діяльності В. Дубровського, слід розрізняти “норми актів" і “норми реакцій”, що формуються навколо двох полюсів: “норма дії - норма винагороди” та “норма відхилення - норма покарання" [12]. Дослідник наголошує на помилковості твердження про поєднання причинно-наслідковим зв'язком “норми актів" та “норми реакцій”. Кожна з них має свій референтний набір відхилень, оскільки “акти діяльності” та "акти реакції” є відображенням різних типів нормування: перші діють на основі відповідності (норма/відхилення), а другі - згідно із встановленими нормами винагороди чи покарання [12, с. 437-435]. Трансляція цих двох окремих норм слугуватиме комунікативній гнучкості, натомість жорстке їх причиннонаслідкове закріплення стигматизуватиме суспільство, блокуватиме процеси соціальної регуляції.

Усе вищесказане актуалізувало звернення до раніше розробленої авторської моделі, щоб уточнити ії пояснювальну придатність у контексті зміни соціальних процесів, регулятивної спроможності різних рівнів соціальної системи та розуміння актуалізації набору соціальнопсихологічних механізмів у ситуації врегулювання соціальних конфліктів. Її розрізнювальну здатність уже було апробовано для аналізу системи надання освітніх послуг, а також розбудови соціальної політики щодо дітей і сім'ї [13]. Розроблена модель, на думку автора, здатна пояснити переходи між рівнями соціального функціонування, фіксуючи механізми індивідуального та соціального реагування і заходи регулювання щодо динамічних викликів історичного розвитку системи. Для кращого розуміння наводимо розроблену модель у контексті динаміки регулювання процесів у соціальних системах та формування локалізації соціальної напруженості (рис.). 


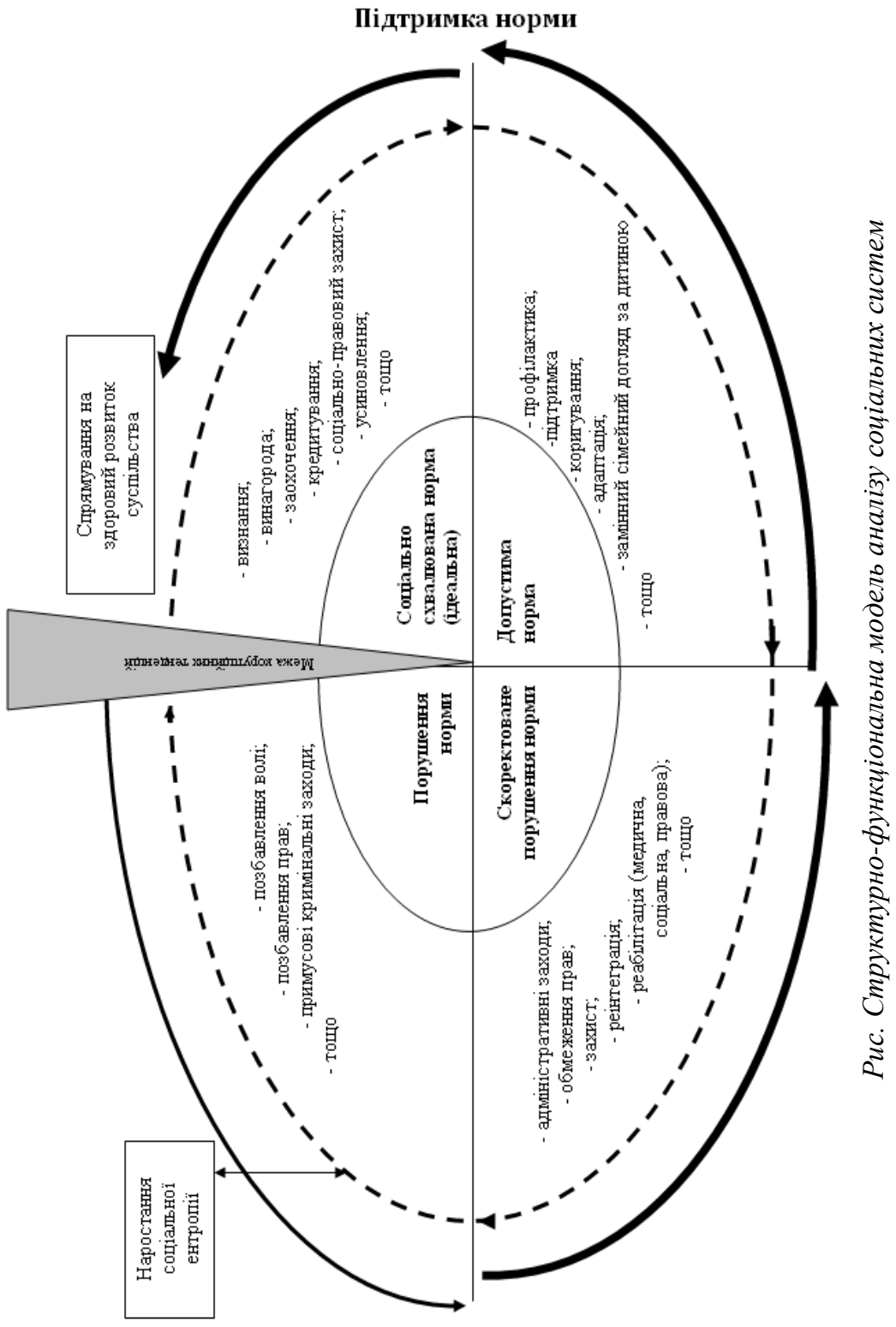

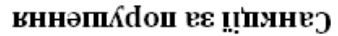


Модель схематично відображає поділ соціальної системи суспільства на чотири сектори нормативного простору, де перший "соиіально схвалювана норма як ідеальна" - передбачає визнання та винагороду за їі дотримання й відтворення. У такий спосіб створюються і транслюються цінності та соціальні норми, стверджуються параметри здорового функціонування, посилюються механізми самовідтворення системи, розвивається іiі адаптаційний потенціал і формуються уявлення та очікування щодо ії перспектив.

Другий сектор - “допустима норма" - фіксує незначні відхилення, які компенсуються та абсорбуються умовами функціонування самої системи. Прикладом соціальних ситуацій цього сектору може бути порушення стану здоров'я людини - тимчасова непрацездатність, що може компенсуватися застосуванням певних методів, у результаті чого відбувається відновлення стану працездатності. Прагнення до відновлення власного стану здоров'я закладається сектором соціально схвалюваної норми, а суб'єктивне відчуття себе здатним до соціального та фізичного функціонування базується на цілій низці підтримувальних механізмів [14]. Почуття задоволення, радості, життєвої спроможності відображаються в певній гуморальній регуляції організму та посилюються на соціальному рівні схвалення та заохочення.

Третій - “скоректоване порушення" - формує підходи щодо допустимості відміни покарання і пошуку можливостей застосування компенсації та абсорбування. Прикладом соціальних процесів цього сектору може бути актуальна в країні освітня реформа, що передбачає створення в школі інклюзивного освітнього середовища [15]. Згідно 3 концепцією інклюзивного навчання, школа як освітній заклад має набути характеристик доступності для навчання дітей з інвалідністю, що знижує ризики поглиблення процесів соціальної “інвалідизаціі”.

Четвертий сектор - “порушення норми” - уособлює крайній вияв, коли ступінь відхилення наскільки високий, що корекція або неможлива, або забороняється (див. рис.). Цей сектор акумулює порушення, що тягнуть за собою кримінальну відповідальність: соціальні явища, які характеризують цей сектор, як правило, пов'язані із злочином, убивством та іншими антисоціальними явищами, що загрожують людському життю. У цьому секторі також “зароджується” і корупція, поширення якої пропорційно буде залежати від зменшення ваги сектору “соціально схвалюваної норми".

У контексті описаної нами моделі типовими є два механізми соціальної регуляції: перший - посилення бажаного засобами винагородження та стимулювання, а другий - за допомогою процесів інгібіції, що зумовлюють послаблення та пригноблення (за рахунок корекції та обмежень, санкцій та покарання). Обидва механізми цілеспрямовано 
зосереджуються на предметі впливу. Розроблена нами модель $є$ жорстко фіксованою і допускає переміщення лише в межах власної системи, що підкреслює ії параметри як окремої одиниці функціонування (межі системи, ідентифікації, атрибути, правила, цінності тощо) та слугує стійкості та стабільності їі структурної організації. Модель відображає природні процеси створення соціальної організації з особливим поєднанням соціального та особистісного, організаційного та індивідуального. Екологічність регуляції такої організації базується на відповідному узгодженні цих двох процесів, один з яких “виходить" від індивіда, а другий - від організації.

У тлумаченні поняття організаиії ми спираємося на методологічні засади, розроблені вітчизняним психологом В. Казміренком [16]. Згідно $з$ теорією систем на життєздатність будь-якої організації буде вказувати переважання в ії розвитку еволюційних змін, а також життествердна спрямованість на дотримання екологічності як щодо своїх членів, так і щодо учасників інших соціальних систем. Слід відмітити, що еволюційний розвиток системи та дотримання екологічних іiі характеристик уможливлюються лише в ситуації відкритого іії функціонування у взаємодії з іншими системами. Будь-які тенденції в напрямі закриття системи будуть свідчити про ії обмеженість та нездатність перейти на новий адаптаційний рівень, який або збалансує внутрішньосистемні механізми регуляції, або зорієнтує на пошук нового напряму розвитку системи на метаадаптаційному рівні.

Напрям розвитку соціальної системи в моделі (див. рис.) позначають дві протилежно спрямовані лінії: пунктирна - в напрямі наростання ентропії, суцільна - у бік посилення соціально схвалюваної норми. Слід зазначити, що сила кожної тенденції формується на індивідуальному та соціальному рівнях одночасно, ініціюючи перерозподіл ваги кожного iз секторів нормативного простору та активізуючи введення в дію системи адаптаційних механізмів. Здатність системи до застосування різних рівнів адаптації буде визначати іiї перспективність або в напрямі стабілізації та набуття нових координат, або в напрямі іiі руйнації та ініціації переділу наявних ресурсів. Цей процес може розвиватися природно, а може супроводжуватися застосуванням певних соціально-політичних технологій. Спрямованість сучасного суспільства на технологізацію управління суспільними процесами змінює погляд на саму людину і їі соціальне функціонування. Це також вносить корективи у процес структурування соціальних систем та його розуміння. Комунікація, як інтегративна характеристика суспільства, змінює свій напрям з безпосереднього контакту на опосередкований, технологізований, із трансформованими параметрами його розгортання в часі та просторі. Розрив, що формується між тілесним (фізичним) життям людини і віртуальним 
простором інформаційного суспільства, потребує переходу на нові рівні соціального функціонування та врахування цих особливостей.

Висновки. Запропонована для аналізу авторська модель відображає динамічні процеси в соціальних системах і може слугувати інтеграції міждисциплінарних знань у розбудові практичних програм розвитку та підтримки соціальних систем шляхом формування та аналізу соціальної політики, державотворення та нормотворення. У контексті знань соціальної психології ця модель може бути рамковою для аналізу розгортання соціальних процесів та інтерпретації отриманих результатів з урахуванням загального стану соціальної системи. Процеси комунікації, що інтегрують соціальну взаємодію, здатні прояснити наявні тенденції і дати краще їх розуміння. Водночас оцінка вияву конфліктної складової може змінюватися з позиції більш широких систем. Натомість кожний соціальний акт, який можна співвіднести 3 певним сектором нормативного простору, може бути індикатором перспективного розвитку певної соціальної системи.

Напрями подальших розвідок. Фіксуючи інтегративні підходи до аналізу соціальних систем та окремих соціальних актів, ця стаття створює прецедент для опанування нових горизонтів розвитку науки в контексті міждисциплінарних знань.

\section{Список використаних джерел}

1. Мертон, Р. (1966). Социальная структура и аномия. В Р. Мертон, Социология преступности (Современные буржуазные теории) (с. 299-313). Москва: Прогресс.

2. Васютинський, В. (2010). Психологічні виміри спільноти. Київ: Золоті ворота.

3. Казміренко, В. П. (Ред.). (2008). Інтеграційні процеси в суспільстві та політичний вибір особистості. Київ: Міленіум.

4. Крам, Т. Ф. (2000). Управление энергией конфликта. Москва: Рефл-бук, ACT.

5. Савчин, М. В. (2011). Буття особистості: онтологічна сутність, структура і темпоральність. Освіта регіону: політологія, психологія, комунікації, 3 , 87-92. Взято з http://social-science.com.ua/article/527].

6. Батраченко, І. Г., \& Прокопенко, Л. Л. (2011). Соціально-психологічні аспекти формування та реалізації державної політики розвитку інформаційного суспільства в Україні. Державне будівництво, 1. Взято 3 http://nbuv.gov.ua/UJRN/DeBu_2011_1_51.

7. Тоффлер, Э. (1997). Футурошок. Санкт-Петербург: Лань.

8. Кочубейник, О. (2017). Психологічний зміст аномії: конструювання опитувальника. Педагогічний процес: теорія і практика, 1, 7-14.

9. Левчук, Н. М. (2011). Асоціальні явища як наслідок дефіциту соціального капіталу в Україні. Український соиіум, 1, 135-147.

10. Сіверс, З. Ф. (Ред.). (2017). Прикладні аспекти становлення політикоправової свідомості молодi. Кропивницький: Імекс-ЛТД. 
11. Маслоу, А. (1997). Психология бытия. Москва: Рефл-бук; Киев: Ваклер.

12. Дубровский, В. (2011). Очерки по общей теории деятельности. Москва: Ин-т развития им. Г. П. Щедровицкого.

13. Бевз, Г. М., Вірковський, В. П., \& Корець, А. Й. (2015). Моделі аналізу надання освітніх послуг для дітей в умовах децентралізації. Вісник післядипломної освіти, 14(27), 22-31.

14. Жуков, Д. А. (2007). Биология поведения: гуморальныле механизмы. СанктПетербург: Речь.

15. Про внесення змін до Закону України “Про освіту” щодо особливостей доступу осіб з особливими освітніми потребами до освітніх послуг. (2017). Відомості Верховної Ради, № 30, ст. 322. Взято 3 http://zakon5.rada. gov.ua/laws/show/2053-19].

16. Казмиренко, В. П. (1993). Социальная психология организащий. Киев: МЗУУП.

\section{References}

1. Merton, R. (1966). Sotsialnaya struktura i anomiya [Social structure and anomy]. In Sotsiologiya prestupnosti (Sovremennyye burzhuaznyye teorii) [Sociology of crime (Modern bourgeois theories)] (pp. 299-313). Moscow: Progress Publ. (rus).

2. Vasiutynskyi, V. (2010). Psykholohichni vymiry spilnoty [The psychological dimensions of the community]. Kyiv: Zoloti vorota Publ. (ukr).

3. Kazmirenko, V. P. (Ed.). (2008). Intehratsiini protsesy $v$ suspilstvi ta politychnyi vybir osobystosti [Integration processes in society and political choice of personality]. Kyiv: Millenium Publ. (ukr).

4. Krum, T. F. (2000). Upravleniye energiyey konflikta [Conflict Management]. Moscow: Refl-buk, AST Publ. (rus).

5. Savchyn, M. V. (2011). Buttia osobystosti: ontolohichna sutnist, struktura i temporalnist [Personality being: ontological essence, structure and temporality]. Osvita rehionu: politolohiia, psykholohiia, komunikatsii [Education in the region: political science, psychology, communication], 3,87-92. Retrieved from http://social-science.com.ua/article/527] (ukr).

6. Batrachenko, I. H., \& Prokopenko, L. L. (2011). Sotsialno-psykholohichni aspekty formuvannia ta realizatsii derzhavnoi polityky rozvytku informatsiinoho suspilstva v Ukraini [Social-psychological aspects of formation and realization of state policy of developing informational society in Ukraine]. Derzhavne budivnytstvo [State building], 1. Retrieved from http://nbuv.gov.ua/UJRN/DeBu_2011_1_51 (ukr).

7. Toffler, E. (1997). Futuroshok [Futuroshok]. St. Petersburg: Lan Publ. (rus).

8. Kochubeynyk, O. (2017). Psykholohichnyi zmist anomii: konstruiuvannia opytuvalnyka [Psychological content of anomie: designing a questionnaire]. Pedahohichnyi protses: teoriia i praktyka [Pedagogical Process: Theory and Practice], 1, 7-14 (ukr).

9. Levchuk, N. M. (2011). Asotsialni yavyshcha yak naslidok defitsytu sotsialnoho kapitalu v Ukraini [Social phenomena as a consequence of a shortage of social capital in Ukraine]. Ukrainskyi sotsium [Ukrainian society], 1, 135-147 (ukr).

10. Sivers, Z. F. (Ed.). (2017). Prykladni aspekty stanovlennia polityko-pravovoi svidomosti molodi [Applied Aspects of Formation of the Political and Legal Consciousness of Youth]. Kropyvnytskyi: Imeks-LTD Publ. (ukr). 
11. Maslow, A. (1997). Psikhologiya bytiya [Psychology of being]. Moscow: Reflbuk Publ.; Kyiv: Vakler Publ. (rus).

12. Dubrovskiy, V. (2011). Ocherki po obshchey teorii deyatelnosti [Essays on the general theory of activity]. Moscow: G. P. Schedrovitsky Institute of Development (rus).

13. Bevz, H. M., Virkovskyi, V. V. \& Korets, A. Y. (2015). Modeli analizu nadannia osvitnikh posluh dlia ditei v umovakh detsentralizatsii [Model analysis providing educational services for children under decentralization]. Visnyk pisliadyplomnoi osvity [Bulletin of Postgraduate Education], 14(27), 22-31 (ukr).

14. Zhukov, D. A. (2007). Biologiya povedeniya: gumoralnyye mekhanizmy [Biology of behavior: humoral mechanisms]. St. Petersburg: Rech Publ. (rus).

15. Pro vnesennia zmin do Zakonu Ukrainy "Pro osvitu" shchodo osoblyvostei dostupu osib z osoblyvymy osvitnimy potrebamy do osvitnikh posluh [On Amendments to the Law of Ukraine "On Education" regarding the peculiarities of access of persons with special educational needs to educational services]. (2017). Vidomosti Verkhovnoi Rady, 30, st. 322. Retrieved from http://zakon5.rada.gov.ua/laws/ show/2053-19] (ukr).

16. Kazmirenko, V. P. (1993). Sotsialnaya psikhologiya organizatsiy [Social psychology of organization]. Kyiv: MZUUP (rus).

(C) Бевз Г. М. 